\title{
THE OCCURRENCE OF MOLDS, YEASTS AND MYCOTOXINS IN PRE-COOKED PIZZA DOUGH SOLD IN SOUTHERN RIO GRANDE DO SUL
}

\author{
Beatriz Helena Pinho' ${ }^{*}$; Eliana Badiale Furlong² \\ ${ }^{1}$ Departamento de Patologia and ${ }^{2}$ Departamento de Química, Fundação Universidade Federal do Rio Grande, \\ Rio Grande, RS, Brasil
}

Submitted: June 07, 1999; Returned to authors for corrections: September 29, 1999; Approved: June 26, 2000

\begin{abstract}
The quality of pre-cooked pizza dough was investigated by assessing the occurrence of molds, yeasts and mycotoxins. Random sampling of commercial pre-cooked pizza cakes was done in different stores in the cities of Rio Grande and Pelotas, RS, between 1996 and 1997. The products were analysed on the sampling day and after storage at room $\left(22-30^{\circ} \mathrm{C}\right)$ or refrigerated temperature $\left(7^{\circ} \mathrm{C}\right)$ following the shelf life stated by the manufacturer (25,30 and 45 days). The results showed that mold and yeast contamination was frequently above the maximum limits $\left(10^{3} \mathrm{CFU} / \mathrm{g}^{-1}\right)$ established by Brazilian guide lines, even in samples kept at refrigerated temperatures up to the end of shelf life. Although no mycotoxin contamination was detected, a strain of the Penicillium genus, isolated from various samples, produced ochratoxin A at refrigeration temperatures.
\end{abstract}

Key words: pre-cooked pizza dough, fungi, mycotoxins

\section{INTRODUCTION}

The bakery industry has been increasing and varying its production during the last few years, and pizza has become very popular. They are sold ready to use, frozen, chilled or pre-cooked in many different commercial establishments. The large consumption of this food is not only due to its flavor but also because it is practical, easy to prepare, has high nutritional value and is cheap.

The dough of pre-cooked pizzas, being a product based on cereals and having intermediary moisture content, is a potential substrate for fungal development, caused by contamination occurring after baking during packaging and inappropriate storage (13).

These fungi can grow and affect the nutritional and sensory properties of the product and if the species are toxigenic, they may produce mycotoxins (4). The occurrence of mycotoxins has been observed worldwide in wheat, peanut, corn, beans and grains, besides meat and milk. In addition, mycotoxins are not completely eliminated by processing $(2,6,10)$.

The aflatoxins $B_{1}, B_{2}, G_{1}, G_{2}$ and ochratoxin $A$ are the most frequent mycotoxins present in grains and foods because they are produced by ubiquitous fungal genera like Aspergillus and Penicillium. The cancerous and nephrological effects of these toxins reinforce the need for a regular search for their occurrence. Due to their peculiar blue and green fluorescence, they can be detected by relatively simple techniques $(10,12,19)$

In the specific case of pre-cooked pizza doughs, wich are baked, the fungi may be inactivated, even though they can contaminate the food again after processing. The mycotoxins may come from the raw material or be produced in the food when contaminated during post baking handling $(4,10,13)$.

The aim of the present work was to study the contamination levels in pre-cooked pizza dough by an assessment of the molds and yeasts present and the identification of the more frequent genera present. The ocurrence of the following mycotoxins: aflatoxins $B_{1}, B_{2}, G_{1}, G_{2}$ ochratoxin $A$ and zearalenone was also determined.

\footnotetext{
* Corresponding author. Mailing address: Fundação Universidade Federal do Rio Grande, Laboratório de Micotoxinas, Rua Alfredo Huch, 475, CEP 96201900, Rio Grande, RS, Brasil.
} 


\section{MATERIALS AND METHODS}

\section{Sampling}

The pre-cooked pizza doughs were acquired from commercial establishments in the cities of Pelotas and Rio Grande in the State of Rio Grande do Sul, Brazil. The three brands chosen had expiration dates within 25,30 and 45 days, according to the manufacturers. Sample collection was performed in the fall, winter and spring of the year of 1996 and the summer of 1997.

Sets of 8 discs of pre-cooked pizza crusts were formed at each sample collection for brands A, B and C.This procedure was repeated three times for each brand comprising 9 experiments and totalizing 72 discs, which constituted the analytical samples. The determinations on the samples were performed at time zero (To), a period between the first and the fifth day after manufacture, and after storage at refrigerated temperature (RFT) $\left(7^{\circ} \mathrm{C}\right)$ and at room temperature (RT) (22$30^{\circ} \mathrm{C}$ ) for up to two days before the end of the corresponding shelf life for to each brand.

\section{Mycological Determinations}

The enumeration of molds and yeasts was performed after using

pour plate technique in acidified potato dextrose agar (PDA) according to A.P.H.A(1984). After enumeration, the most frequent fungal colonies found in the pre-cooked pizza crusts were isolated and kept in Sabouraud agar until the identification procedures were completed.

The results of the enumeration using PDA were compared with those obtained using a Petrifilm YM 3M in one experiment (15).

The identification of the most frequent genera in PDA was effected from the macroscopical and microscopical characteristics of the colonies and microcultive $(11,15,16)$.

\section{Determination of Aflatoxins $B_{1}, B_{2}, G_{1}, G_{2}$ ochratoxin $A$ and zearalenone}

A thin layer chromatographic method (19) was used for the simultaneous detection of aflatoxins B1, B2, G1, G2, ochratoxin $\mathrm{A}$ and zearalenone. The toxins were extracted using methanol and $4 \% \mathrm{KCl}(9+1)$, followed by clarification with ammonium sulfate and partition with chloroform. Confirmation was accomplished by chemical reaction $(8,17)$, elution with different solvents and co-chromatography.

The determinations were performed on the pre-cooked pizza cakes at time zero and after storage at refrigerated temperature $\left(7^{\circ} \mathrm{C}\right)$ and at room temperature $\left(22-30^{\circ} \mathrm{C}\right)$ for up to two days before the corresponding expiration date of each brand and on the isolated fungal cultures, incubated in Sabourand agar under the same conditions as the pizza doughs.

The detection limits of the method were 1.7; 6.5 and 60 ng.g ${ }^{-1}$ for aflatoxins, ochratoxin A and zearalenone respectively (3).

\section{RESULTS AND DISCUSSION}

The enumeration of mold and yeast was done using a PDA media because it is convenient for screening a large number of species, and the observations can be made over an extended period of time on a single colony. $(3,7)$. This was observed during previous studies where bread was used as a model (3).

As for Beuchat et al. (16) no differences between the enumeration on Petrifilm and on PDA during the test experiment. The latter was chosen because of its lower cost and the ease of recovering fungi for identification procedures. The average results of the enumeration of molds and yeasts on PDA for the three studied brands are presented in Table 1 .

Table 1: Enumeration of molds and yeasts for pre-cooked pizza dough before and after being stored

\begin{tabular}{lccc}
\hline Samples & $\begin{array}{c}\text { TO } \\
\text { CFU.g }\end{array}$ & $\begin{array}{c}\text { RFT } \\
\text { CFU.g }\end{array}$ & $\begin{array}{c}\text { RT } \\
\text { CFU.g-1 }\end{array}$ \\
\hline A1 & $1.3 \times 10^{4}$ & $7.2 \times 10^{4}$ & $2.9 \times 10^{6}$ \\
A2 & $1.6 \times 10^{4}$ & $1.4 \times 10^{4}$ & $2.5 \times 10^{6}$ \\
A3 & $4.3 \times 10$ & $9.6 \times 10^{3}$ & $2.8 \times 10^{6}$ \\
B1 & $2.0 \times 10^{2}$ & $2.7 \times 10^{6}$ & $6.8 \times 10^{3}$ \\
B2 & $9.2 \times 10^{2}$ & $4.1 \times 10^{3}$ & $1.51 \times 10^{4}$ \\
B3 & $1.2 \times 10^{2}$ & $4.7 \times 10^{4}$ & $9.5 \times 10^{4}$ \\
C1 & $7.9 \times 10$ & $4.8 \times 10^{3}$ & Mold \\
C2 & $1.1 \times 10^{2}$ & $1.6 \times 10^{4}$ & $1.2 \times 10^{4}$ \\
C3 & $1.4 \times 10^{2}$ & $2.1 \times 10$ & Mold \\
\hline
\end{tabular}

TO: zero time

RFT: refrigerated temperature $\left(7^{\circ} \mathrm{C}\right)$

RT: room temperature $\left(22-30^{\circ} \mathrm{C}\right)$

A, B, C: brands of pre-cooked pizza cakes

$1,2,3$ : periods of sample collection

According to the Brazilian guideline, the maximum tolerated level for molds and yeasts in baked products is $5 \times 10^{3} \mathrm{CFU} \cdot \mathrm{g}^{-1}$ (Ministery of Health, SVS portaria 451, 19/09/97). According to DINAL (Divisão Nacional de Alimentos), another national organization food control, the maximum level for molds and yeasts is $10^{4} \mathrm{CFU} \cdot \mathrm{g}^{-1}(5)$. The most contaminated sample was brand $\mathrm{A}$, with respect to molds and yeasts, at the moment of sampling.

All the brands of pre-cooked pizza doughs showed values higher than the limits established by the national control boards to molds and yeasts, after storage at room and refrigerated temperatures. In general, the samples stored at refrigerated temperatures showed lower values of CFU. $\mathrm{g}^{-1}$. This was due to refrigeration temperatures slowing down the exogenous or endogenous degradation reactions.

An interesting proposal was made by Rayman et al. (18), for the adequacy of baked products. According to their criteria, 
in terms of molds and yeasts, the limit between acceptable quality and marginal quality is $2 \times 10^{3} \mathrm{CFU} . \mathrm{g}^{-1}$ and the limit separating marginal quality from unacceptable quality is $5 \times 10^{4} \mathrm{CFU} . \mathrm{g}^{-1}$.

According to the above mentioned proposal (18) the precooked pizzas doughs, stored at room temperature, were not recommended for consumption. Storage at refrigeration temperature was not sufficiently effective to avoid the samples being considered of marginal quality with respect to their molds and yeasts counts.

The identification of the genera was effected from the macroscopical and microscopical characteristics of the colonies and the microcultive showed that the fungi belonging to the genera Penicillium and Aspergillus were more frequent. Others genera present were identified as Mucor sp, Geotrichium sp and yeasts. These fungal genera are present in the environment and easily contaminated food.

These results suggest that more care should be taken in the handling of these products after they are baked, that storage should be done under refrigeration and also that the established shelf life period should be reviewed. Another aspect that might be studied is the type of package to be recommended for this kind of product. All these parameters determine the fungal recontamination of baked and cooked products.

The study of mycotoxins in pre-cooked pizza doughs is justified due to their thermostability, allowing for their presence in the raw material used in the pizza dough formulation. Although the fungi and their spores may be destroyed by the thermal treatment during baking, the product can be recontaminated in the next steps by toxigenic fungi present in the environment $(3,10$, 14). In these specific cases the probabiliy of mycotoxin occurrence was high because the number of forming colony units was high.

During screening for aflatoxin $\left(B_{1}, B_{2}, G_{1}, G_{2}\right)$, ochratoxin $A$ and zearalenone it was shown that $22 \%$ of the samples were probably contaminated, although this was not confirmed during the confirmatory test. These results imply that the raw material used in the manufacture of the products did not present at detectable levels of toxins after formulation. The high number of samples with false positive results may be caused by fluorescent components in the formulation or have been formed during baked. We can't discard the possibility of contamination by some other mycotoxins not researched here.

A previous survey of mycotoxins in pre formed loaves conducted in our laboratory showed the occurrence of ochratoxin A in moldy pre-form loaves during the shelf life period (3). This suggested the possibility that an extended storage under unsuitable conditions could lead to the occurence of mycotoxins if there were toxigenic fungal species present.

Considering the above mentioned information, three types fungal colonies frequently found in pre-cooked pizza dough, belonging to the Penicillium genera and denominated I, II and III, were submitted to a screening chemical test for toxigenicities (14). The isolated colonies were incubated in Sabourand agar under the same conditions (time and temperature) as the commercial products. They were then submitted to the multimethods proposed by Soares, taking care to follow the methods specified to determine mycotoxins (19). The results are presented in Table 2.

Table 2. Screening of mycotoxins in fungal colonies isolated from pre-cooked pizza cakes.

\begin{tabular}{cccc}
\hline Colony & $\begin{array}{c}\text { RFT } \\
(25 \text { days })\end{array}$ & $\begin{array}{c}\text { RFT } \\
(45 \text { days })\end{array}$ & $\begin{array}{c}\text { RT } \\
(25 \text { days })\end{array}$ \\
\hline I & *ochratoxin A & *ochratoxin A & *ochratoxin A \\
II & - & Aflatoxins $\mathrm{B}_{1}$ e B & - \\
III & *ochratoxin A & *ochratoxin A and & - \\
& & Aflatoxins $\mathrm{B}_{1}$ e B & \\
\hline
\end{tabular}

I, II, III: Penicillium fungal colonies

RFT: refrigerated temperature $\left(7^{\circ} \mathrm{C}\right)$

RT: room temperature $\left(22-30^{\circ} \mathrm{C}\right)$

* confirmed presence of ochratoxin A

The choice of the incubation conditions was according to the shelf life of the brand from which the colonies were isolated. Only one colony incubated at room temperature producted ochratoxin A after 25 days, colonies II and III produced the toxins at refrigerated temperatures after 45 and 25 days respectively. This is a characteristic of many toxigenic Penicillium species mencioned by other authors $(7,10,15)$. Unfortunately the species was not identified in this work.

\section{CONCLUSIONS}

The number of colony forming units of molds and yeasts increased during storage at the temperatures studied, being more intense when the samples were stored at room temperature.

The storage of the pre-cooked pizza dough at refrigerated temperatures was not effective in keeping the number of colony forming units in the samples within the limits established by the legislation during the shelf life period.

The samples of pizza dough were not contaminated with aflatoxins $B_{1,} B_{2}, G_{1}, G_{2}$, ochratoxin A or zearalenone at the time of sample collection or after storage during the shelf life.

Fungal colonies belonging to the Penicillium genus produced ochratoxin A under the time and temperature conditions established in this work.

\section{RESUMO}

\section{Ocorrência de bolores, leveduras e micotoxinas em massa de pizza pré-fabricada comercializada no Rio Grande do Sul}

A qualidade de massa de pizza pré-fabricada foi avaliada através da determinação de bolores, leveduras e micotoxinas. 
Entre 1996 e 1997, fez-se uma amostragem ao acaso de discos de pizza pré-cozidos, em diferentes estabelecimentos comerciais das cidades de Pelotas e Rio Grande, RS, Brasil. Os produtos foram analisados no dia da amostragem e após o armazenamento em temperatura ambiente $\left(22-30^{\circ} \mathrm{C}\right)$ ou de refrigeração $\left(7^{\circ} \mathrm{C}\right)$, seguida o prazo de validade indicado pelo fabricante $(20,30 \mathrm{e}$ 45 dias). Os resultados indicaram que contaminação por bolores e leveduras estavam frequentemente acima dos limites $\left(10^{3} \mathrm{UFC} /\right.$ g), estabelecidos pelos padrões brasileiros, mesmo nas amostras mantidas em refrigeração. Embora nenhuma micotoxina tenha sido detectada, uma cepa do gênero Penicillium, isolado de várias amostras, produziu ocratoxina $\mathrm{A}$ em refrigeração.

Palavras-chave: massa de pizza pré-cozida, fungos, micotoxinas

\section{REFERENCES}

1. American Public Health Association. Wasthington. Compedium of Methods for the Microbiological Examination of Foods, Washington, DC, 1984.

2. Badiale-Furlong, E Tricotecenos em trigo: um estudo de metodologia analítica, incidência, contaminação simultânea por outras micotoxinas $e$ de alguns fatores que influem na produção no campo, Campinas, 1992.(Ph D Thesis, Universidade Estadual de Campinas, Faculdade de Engenharia de Alimentos).

3. Badiale-Furlong, E. Avaliação de incidência de micotoxinas em microbiota fúngica em produtos de panificação. Relatório técnico encaminhado à FAPERGS, Rio Grande, RS, 1996.

4. Baggerman, W.I, Samson, R. A Heat Resistence of Fungal Spores. In: Identication of the Comonn Food-Borne Fungi $3^{\mathrm{a}}$ ed Institute of the Royal Netherlands Academy of Artsand Sciences, 1988.
5. Comissão Nacional de Normas e Padrões: In: Compêndio de Resoluções da CNNPA, Associação Brasileira da Indústria de Alimentos - ABIA, São Paulo, 1995.

6. Farfallini, F., Krivoruchco, D. Estudio del almacenamiento em atmósfera modificada de pizzetas de harina integral Buenos Aires, Segundo Simpósio Internacional de la Seccion de America Latina y el Caribe de la A.O.A.C. International, 1997, p.48.

7. Griffin, D.H. Fungal Physiology, $2^{\text {nd }}$. Edition, Wiley-Liss, New York, 1994, p. 458.

8. Hunt, D.C., McConnie, B.R., Crosby, N.T. Confirmation of ocratoxin A by chemical derivatization and high performance liquid chromatography. Analyst., 105: 89-90, 1980.

9. Milanez, T.V., Leitão, M.F.F. The effect of cooking on ochratoxin A content of beans, variety carioca. Food Addit. Contamin., 13(1): 89-93, 1996.

10. Moss, O.M. Secondary metabolism and food intoxication-moulds. J. Appl. Bacteriol. Symp. Supplem. 73:80S-88S, 1992.

11. Northolt, M.D.; Soentoro, P.S. Fungal Growth on Foodstuffs Related to Mycotoxin Contamination. Identification of the comonn Food-Borne Fungi, 3ed. Institute of the Royal Netherlands Academy of Artsand Science, 1988.

12. Osborne, B.G et al, The effects of milling and processing on wheat contaminated with ochratoxin A. Food Addit. Contam., 13 (2):141-153, 1996.

13. Oosborne, B.G. Mycotoxins and the cereals industry. J. Food Technol.17:19, 1982.

14. Piñeiro, M. S. Diferenciacion entre hongos toxigenicos y atoxygenicos. In: Micotoxinas Perspectivas Latinoamericana. Ed. Luis Celso Hygino da Cruz, Editora Universidade Federal do Rio de Janeiro, 1996, p.220.

15. Pitt, J.I. Recent developments in the study of Penicillium and Aspergillus systematics. J. Appl. Bacteriol. Symp. Supplem., 1989, p.37S-45S.

16. Pitt, J.I.; Hocking, A.D. Fungi and Food Spoilage, $2^{\text {nd }}$. Edition. Blackie Academic \& Professional, London, 1997.

17. Przybylski, W. Formation of aflatoxin derivatives on thin layer chromatographic plates. J. Assoc. Off. Analyt. Chem., 58:163-164, 1975.

18. Rayman, M.K. et al Microbiological quality of pasta products sold in Canada. J. Food Prot. 44(10): 746-749, 1981.

19. Soares, L.M.V. Micotoxinas:um método para análise simultânea e incidência em alimentos comercializados na região de Campinas São Paulo, Campinas: Universidade Estadual de Campinas Faculdade de Engenharia de Alimentos, 1987. 